\title{
Helicobacter pylori Recent advances in the study of its pathogenicity and prevention
}

Germán R.A guilar, M.S., Ph.D., ${ }^{(1)}$ Guadalupe Ayala, M.S., Ph.D., (1) Geny Fierros-Zárate, Q .B. ${ }^{(1)}$

Aguilar GR,Ayala G, Fierros-Zárate G. Helicobacter pylori: Recent advances in the study of its pathogenicity and prevention.

Salud Publica Mex 2001;43:237-247.

The English version of this paper is available at: http://www.insp.mx/salud/index.html

\begin{abstract}
Helicobacter pylori has acquired great importance during the last two decades, after being recognized as an important patho gen that infects a great portion of the human population. This microorganism is recognized as the main causal agent of chronic gastritis and duodenal ulcers, and it is associated with the subsequent development of gastric carcinoma. The pathogenic mechanisms of $\mathrm{H}$. pylori and their relation to gastric ailments have not been clearly defined. However, at present it is well established that urease, vacuolating cytotoxin VacA, and the pathogenicity island (cag PAI) gene products, are the main factors of virulence of this organism. Thus, individuals infected with strains that express these virulence factors probably develop a severe local inflammation that may induce the develo pment of peptic ulcer and gastric cancer. The way the infection spreads throughout the world suggests the possibility that there are multiple pathways of transmission. Due to the importance that $H$. pylori has acquired as a human pathogen, laboratories worldwide are attempting to develop a vaccine that confers long-term immunological protection against infection by this microorganism. Hence, the objective of this review is to present the most relevant findings of the biology of $\mathrm{H}$. Pylori and its interaction with the human host.The full version of this paper is available too at: http:// www.insp.mx/salud/index.html
\end{abstract}

Key words: Helicobacter pylori; gastric cancer; vaccination

\author{
Aguilar GR,Ayala G, Fierros-Zárate G. \\ Helicobacter pylori: avances recientes \\ en el estudio de su prevención \\ y patogenicidad. \\ Salud Publica Mex 2001;43:237-247. \\ El texto completo en inglés de este artículo está \\ disponible en: http://www.insp.mx/salud/index.html
}

\section{Resumen}

Helicobacter pylori ha adquirido gran importancia durante las últimas dos décadas, al ser reconocido como un importante patógeno que infecta una gran porción de la población humana. Este microrganismo es reconocido co mo el principal agente que causa la gastritis crónica y la úlcera duodenal, además de que se ha asociado con el subsecuente desarrollo del carcinoma gástrico. Los mecanismos patogénicos de H. pylori y su relación con los padecimientos gástricos no se han definido en forma clara. Sin embargo, actualmente está bien establecido que la ureasa, la citotoxina vacuolizanteVacA y los productos de los genes de la isla de patogenicidad (cag PAI) son los principales factores de virulencia de este organismo. Así, los individuos infectados con cepas que expresan dichos factores de virulencia, probablemente manifiesten una marcada inflamación local que podría inducir el desarrollo de úlcera péptica y cáncer gástrico. La manera como la infección se propaga a nivel mundial sugiere la posibilidad de múltiples vías de transmisión. A consecuencia de la importancia que $\mathrm{H}$. pylori ha adquirido como patógeno humano, los laboratorios del mundo se esfuerzan para desarrollar una vacuna que confiera protección inmunoló gica de larga duración contra la infección por este microorganismo. El objetivo de esta revisión es presentar los hallazgos más relevantes sobre la biología de $\mathrm{H}$. pylori y su interacción con su huésped humano. El texto completo de este artículo también está disponible en: http:/ /www.insp.mx/salud/index.html

Palabras clave:H elicobacter pylori; cáncer gástrico;vacunación

This work was supported in part by Consejo N acional de Ciencia y Tecnología (C onacyt); grant MO 214 and Instituto N acional de Salud Pública.

(1) Centro de Investigación sobre Enfermedades Infecciosas, Instituto N acional de Salud Pública, México.

Received on: May 17,2000 • Accepted: December 13,2000

Reprint requests to: Dr. Germán R.Aguilar. Centro de Investigación sobre Enfermedades Infecciosas, Instituto N acional de Salud Pública. Av. Universidad 655, Cuernavaca, 62508 Morelos, México. E-mail: graguila@ insp3.insp.mx 
$H$ elicobacter pylori was probably already established in the human stomach at least 100000 years before the beginning of the human exodus from Africa and thereafter it followed humans as an unknown pathologic agent. ${ }^{1}$ However, in 1982 this bacterium was removed from the group of the unrecognized etiologic agents when it was discovered and isolated through accidental extended incubation of pure culture from human gastric mucosa biopsies. ${ }^{2,3}$ These events and subsequent studies of its genome sequence, physiology, adaptation to a restricted ecological niche, and possible antigenic variation mechanisms, have changed radically the gastroenterology and microbiology knowledge. H. pylori is a microaerophilic, Gram-negative, slow-growing, spiral-shaped, and flagellated bacteria. To date, H. pylori is a well-recognized pathogen that chronically infects the stomachs of up to $50 \%$ of the world's human population, and that has been associated with serious diseases with significant morbidity and mortality.

\section{Association between $H$. pylori infection and disease}

As with most infectious diseases, Helicobacter associated gastritic disease is influenced not only by the nature of the infecting strain but also by the host and environmental factors. H. pylori infection is confined to the gastric mucosa, where it stimulates a marked local inflammation and a systemic immune response. ${ }^{4}$ Over the long term, susceptible individuals are at risk of developing complications. Gastric inflammation leads to atrophy and metaplasia, conditions strongly associated with stomach cancer. ${ }^{5}$

Since $H$. pylori research has developed rapidly, it is now possible to establish a conclusive link between $H$. pylori and different forms of gastroduodenal abnormalities. ${ }^{6}$ Experiments using human volunteers and animal models have substantiated the strong direct relationship between $H$. pylori and gastritis. Two welldescribed studies of self-inoculation with consistent temporality have been performed.$^{7-9}$ Although none of the experiments using humans volunteers have linked $H$. pylori infection with peptic ulcer disease of the stomach and duodenum, several laboratories have provided a mass of strong circumstantial evidence. ${ }^{10,11}$ Similarly, other studies have established a strong relationship between $H$. pylori infection and gastric adenocarcinoma, although the nature of the relationship is still controversial. ${ }^{12-15}$ Moreover, there is a strong association between $H$. pylori infection and low-grade gastric lymphoma arising from mucosa-associated lymphoid tissue. ${ }^{16} \mathrm{H}$. pylori infection also has been associated with dyspepsia and non-ulcer dyspepsia, although this association is still unresolved. ${ }^{17}$ Taken all together, $H$. pylori infection in humans represents a serious public health concern. Each year, there are at least 7 million patients around the world who are affected by these diseases, leading to hundreds of thousands of deaths. ${ }^{18}$ The World Health Organization classifies this bacterium as a Type 1 carcinogen. ${ }^{19}$

Although $H$. pylori infection is minimally invasive, metaplastic gastric tissue may also spread to other parts of the alimentary tract such as the duodenum, ${ }^{20}$ the proximal esophagus, ${ }^{21}$ the distal esophagus, ${ }^{22}$ Meckel's diverticulum, ${ }^{23}$ and the rectum. ${ }^{24}$ In addition, it has been proposed that although $H$. pylori infection is circumscribed to the gastric mucosa, it could conceivably produce lesions remote to the primary site of infection, by altering levels of systemic inflammatory mediators. ${ }^{25}$ Several non-gastrointestinal tract diseases associated with $H$. pylori infection include diabetes mellitus, thyroiditis, heart diseases, rheumatoid arthritis, dermatological disorders, hepatic encephalopathy, childhood anemia and several more. Nevertheless, the hypotheses that have linked $H$. pylori infection to this variety of non-gastrointestinal tract diseases have not yet been fully substantiated. ${ }^{26,27}$

Although $H$. pylori infection may cause other diseases in addition to gastritis, there are no clinical consequences whatsoever in 60 to $70 \%$ of infected humans. This suggests that $H$. pylori-associated disease is influenced not only by the pathogenic nature of the infecting strain but also by other factors. Genetic variability in host factors such as gender, ${ }^{28,29}$ blood group antigens, ${ }^{30}$ human lymphocyte antigen type, and the age of the host when the infection was acquired, may play a primary role in determining different clinical outcomes. ${ }^{31}$

Environmental factors may also play a role in the outcome of the infection. Socioeconomic class, which affects living conditions and sanitation, may increase the risk of exposure to the bacterium. ${ }^{32,33}$ Tobacco smoking increases the risk of duodenal ulceration for patients infected with $H$. pylori ${ }^{34}$ All these environmental determinants may undergo synergistic or antagonistic interactions with $H$. pylori to render different clinical outcomes of infection. Similarly, dietary factors including high salt and low antioxidant intake are risk factors for gastric carcinoma in and of themselves. ${ }^{35-37}$ However, a vegetable and fruit diet exerts a protective influence against this disease. ${ }^{38}$

Therefore, not everyone infected with pathogenic strains is expected to develop this condition. 


\section{Epidemiological features of the infection}

Although $H$. pylori infection is chronic and endemic, it has distinct epidemiological features..$^{39}$ The prevalence of the infection can vary widely between and within population groups. The prevalence of infection in third world countries seems to be nearly universal, beginning in early childhood and increasing with advancing age. Most children are infected in the first few months of life. By the age of five, as many as $50 \%$ are already infected, and by the age of $40,90 \%$ are infected. ${ }^{40}$ Prevalence rates are lower in developing countries with better industrialization, public health, and living conditions. Nevertheless, the rate is still several times higher than that found in developed countries, where the incidence of $H$. pylori infection is found in approximately $30 \%$ of the adult population. ${ }^{1}$

$H$. pylori incidence has become less frequent in developed countries over recent years, which reflects a so-called cohort effect. The rate of decline may be as high as $26 \%$ per decade ${ }^{41}$ and only $0.4 \%$ of uninfected adults acquire $H$. pylori each year. ${ }^{18}$ In children, however, the incidence may be higher, which is consistent with the notion that $H$. pylori infection is predominantly acquired in childhood. Nevertheless, even in children, the prevalence of infection seems to be diminishing over time. This is a worldwide phenomenon that is likely due to improvements in nutrition, drinking water, and introduction of antibiotics. Moreover, declining family size reduces the opportunity for transmission and increases the age of acquisition.

To date, almost all epidemiological studies have shown an inverse relationship between $H$. pylori infection and socioeconomic status. ${ }^{32}$ In the United States, non-Hispanic whites exhibit lower prevalence of infection than do African-Americans and Hispanics. ${ }^{26,42,43}$ Variations in H. pylori prevalence between different racial and ethnic groups have also been observed in other countries, such as Taiwan and Belgium. ${ }^{44,45} \mathrm{Al}-$ though the reasons for these differences are not well understood, socioeconomic status during childhood is thought to play a significant role. ${ }^{18}$ A genetic predisposition to infection is also feasible. Studies of monozygotic and dizygotic twins show that genetic effects influence the acquisition of $H$. pylori due to great similarities within the monozygotic pairs. ${ }^{46}$ In addition, men consistently have a higher prevalence rate than that of women across all strata of race/ethnicity, age, education, and income. ${ }^{26,47,48}$

Exactly how the organism is transmitted from the stomach of one person to that of another remains unclear. The most accepted hypothesis is that the organism is transmitted through close personal contact and that the human being is the only significant reservoir of infection. ${ }^{49}$ The detection of the bacterium in saliva, dental plaque, diarrheal stools, and vomit implicates oral-oral or fecal-oral transmission as possible routes of infection. Contaminated water and raw vegetables could be a source of $H$. pylori in the fecal-oral transmission pathway. ${ }^{50}$ Iatrogenic spread, through the use of improperly cleaned endoscopic equipment, has also been proposed as a possible route of infection. ${ }^{51}$ There is also the possibility of zoonotic transmission because $H$. pylori has also been found in some domestic animals who have close human contact, such as cats, but at present, the risk of infection from them appears insignificant. ${ }^{52}$ Nevertheless, the demographic, environmental and zoonotic factors may play a role in the spread of $H$. pylori around of the world.

\section{Relevance of strain types of $H$. pylori in the outcome of infection}

Virulence is concept intimately linked to disease and is usually measured in terms of morbidity and mortality. Survival and multiplication are clearly the microbe's priorities, while disease is simply a manifestation of the complex interactions required to accomplish these goals. Thus, virulence determinants include all the factors contributing to the evolutionary success of the parasite, as well as to the development of the disease in the host. There are many virulence factors of $H$. pylori that contribute in dissimilar ways to gastric mucosal damage; among them are factors known to be required for the colonization and survival of $H$. pylori in the human stomach. These factors are urease and flagella that are expressed by all Helicobacter species. H. pylori manufactures large amounts of urease that helps to break down urea into carbon dioxide and ammonium, which neutralizes the acid during colonization of the stomach. The protection of $H$. pylori by this enzyme also induces apoptosis of gastric cells in vitro and inhibits gastric somatostatin release in animals, which could have consequences for the physiology of digestion in general. ${ }^{53}$ Flagellar motility of Helicobacter species has been shown to be essential for successful colonization of the host. Flagella allow the bacterium to swim across the viscous gastric mucus and reach the more neutral $\mathrm{pH}$ underneath the mucus. This property also enables the bacterium to resist the muscular contractions that regularly empty the stomach. Mutants of the urease ${ }^{54}$ or flagellar structure genes ${ }^{55}$ are defective in colonization in animal models of infection.

In analogy with other enteropathogens, the adhesion to the intestinal epithelium is a critical initial step 
in enteric colonization. The adhesion process of certain strains of $H$. pylori can stimulate pedestal formation and develop attaching-effacing lesions, similar to those produced by a special class of enterovirulent Escherichia coli cells. ${ }^{56}$ It has been shown that several putative adhesins mediate the attachment of $H$. pylori to gastric epithelial cells. ${ }^{57-59}$ This suggests that this bacterium could use several adherence mechanisms to establish contact with the surface of the epithelial cells. Nevertheless, despite the importance of the adhesins in colonization and virulence, they have not been proven to be essential for in vivo survival of H. pylori. ${ }^{60}$

H. pylori lipopolysaccharide (LPS) has also been implicated in another aspect of the pathogenesis of $H$. pylori infection. LPS is a family of toxic phosphorylated glycolipids in the outer membrane of Gram-negative bacteria and is composed of a lipid moiety (termed lipid A), a core oligosaccharide, and a polymeric O-specific polysaccharide chain. ${ }^{61}$ Although, $H$. pylori LPS shares certain biological properties with LPS of other intestinal bacteria, generally it possesses lower immunological activity. $H$. pylori LPS is able to induce toxic lethality in animal models ${ }^{62}$ and the secretion of cytokines by human monocytes. ${ }^{63,64} \mathrm{Howev}-$ er, this induction is weaker than that of other tested bacterial LPS. This lower immunological activity of $H$. pylori LPS is probably a result of its unusual acylation and phosphorylation pattern of lipid A. ${ }^{63}$

H. pylori LPS may have an important role in autoimmune-mediated damage in the gastric mucosa. The structure of the LPS O-specific chain in different $H$. pylori strains may mimic Lewis blood group antigens in structure. As these antigens are present in the normal human gastric mucosa, the expression of Lewis antigens on the bacterial surface may camouflage the bacterium and may contribute to its survival in the stomach. ${ }^{61}$ Alternatively, during infection, highly conserved immunogenic molecules expressed by infectious pathogens may act as a trigger for the induction of humoral and cellular immune responses that cross-react with host cellular antigens in a mechanism known as antigenic mimicry. ${ }^{65}$ Antibodies against $H$. pylori Lewis antigens have been found to cross-react with various components of the gastric mucosa. The gastric $\mathrm{H}^{+}, \mathrm{K}^{+}$-ATPase is a major autoantigen in $\mathrm{H}$. pylori-associated antigastric autoimmunity. ${ }^{66}$ Anti-Lewis ${ }^{Y}$ antibodies induced by $H$. pylori against Lewis ${ }^{\mathrm{Y}}$ epitopes of the beta chain of this proton pump involved in acid secretion may promote the development of atrophic gastritis. 65,67

On the other hand, of the molecules that are actively transported to surrounding tissues, the most important is the vacuolating toxin (VacA), which is the major toxin secreted by H. pylori. ${ }^{68}$ The active cytotoxin is produced by approximately $50 \%$ of $H$. pylori clinical isolates ${ }^{69}$ and its presence is associated epidemiologically with tissue damage and peptic ulcers, ${ }^{70}$ VacA is initially translated as a $140 \mathrm{kDa}$ protoxin, which subsequently undergoes both $\mathrm{N}$-terminal and C-terminal processing to yield a $95 \mathrm{kDa}$ mature secreted monomer. This mature monomer assembles into a large oligomeric complex with hexameric or heptameric radial symmetry. The mature monomer could be cleaved proteolytically into two fragments: an N-terminal $34 \mathrm{kDa}$ fragment and a C-terminal $58 \mathrm{kDa}$ fragment that remain associated after cleavage. ${ }^{71}$ The ability to induce vacuoles is localized mostly but not entirely in the first fragment, whereas the second fragment is mostly involved in cell targeting.

Several mechanisms of VacA toxic activity against the host cell have been reported. It has been suggested that this toxin induces the alteration of intracellular vesicular trafficking in eukaryotic cells, leading to the formation of large vacuoles containing markers of late endosomes and lysosomes. ${ }^{72}$ It also causes a reduction in transepithelial electrical resistance in polarized monolayers and forms ion channels in lipid bilayers. ${ }^{73}$ Moreover, it interferes with antigen presentation to the immune system by impairing processing and maturation of the antigen by the antigen-presenting cell. ${ }^{72,74,75}$ Finally, Yahiro K and colleagues reported that acidic and alkaline treatments of VacA protein were associated with an increase in its biological activity and in its binding to a $250-\mathrm{kDa}$ receptor protein-tyrosine phosphatase $\beta$ in AZ-521 cells. ${ }^{76}$

The vacuolating cytotoxin gene A (vacA), which encodes VacA protein, is present in all H. pylori strains, but the structure among vacA alleles varies, particularly in two regions. ${ }^{77}$ One of these regions is the midregion of the gene, which may be type $\mathrm{m} 1$ (subtype a) or $\mathrm{m} 2$ (subtype $\mathrm{a}$ or $\mathrm{b}$ ). The other variable region of vacA gene is in the second half of the signal sequence, which may be type s1 (subtype a, b and c) or s2. ${ }^{78}$ The final structure of vac $A$ gene is a mosaic, and all combinations of signal sequence and mid-region types, including the rare $\mathrm{s} 2 / \mathrm{m} 1$, have been reported. ${ }^{77,79}$ Thus, several different families of $v a c A$ alleles are present in $H$. pylori, and its encoded products are associated with and without vacuolating activity in vitro. ${ }^{77,80}$ Likewise, $H$. pylori strains containing certain types of vacA alleles have been associated with an increased risk for peptic ulcer disease. Atherton and colleagues showed that strains with vacA mid-region type $\mathrm{m} 1$ are more strongly associated with increased gastric epithelial damage (epithelial degeneration, mucus depletion, and microscopic erosion) than mid-region type m2. Meanwhile, 
s1a strains are associated with increased mucosal neutrophil and lymphocyte infiltration in vivo. These results suggest that $\mathrm{s} 1 \mathrm{a} / \mathrm{m} 1$ strains have the most virulent allelic type activity, ${ }^{77,80}$ while vacA s2 strains are rarely associated with ulcer disease and are uncommon in many populations. ${ }^{80-84}$

The link between the ability of a strain to induce epithelial cell vacuolation in vitro and peptic ulcer disease in vivo seems to be consistent but not invariable. ${ }^{77}$ Among strains from populations in the United States, the ability of vacA sla strains to induce ulcer disease was higher than that of vacA s1b strains. Over $90 \%$ of patients with duodenal ulcer disease harbored vacA s1a strains, while patients with vacA s2 strains were not more likely to have ulcer disease than uninfected patients. ${ }^{80}$ Likewise, in a United Kingdom study population, all patients with ulcer disease had vacA s1 strains, and no vacA s2 strains were associated with this disease. ${ }^{83}$ Other studies from Europe also indicate a strong correlation between the vacA s1 genotype and peptic ulceration. ${ }^{85-87}$

However, this correlation is not as evident in the Far East as it is in the West. Recent studies show that most $H$. pylori strains in Japan have an s1a/m1 genotype. However, regardless of the vacA genotype, the infection leads to peptic ulcer or gastric cancer in only a small subset of infected patients. Thus, these H. pylori vacA genotypes cannot be used in a reliable way to discern the risk of developing serious gastroduodenal disease in the host. ${ }^{78,82,88}$

In contrast with East Asian and Western populations, studies of the South African population have shown a high prevalence of the vacA s1b strains in patients with peptic ulceration. No vacA sla strains were present, and $100 \%$ of patients with peptic ulceration harbored strains with vacA s1b allele. ${ }^{84}$ The high prevalence of strains with vacA s1b genotype is not confined to South Africa; these strains are also widespread in Brazil and Portugal, where higher prevalence rates of peptic ulceration and gastric adenocarcinoma have been reported. ${ }^{86,89}$ Additionally, in the South African population, the vacA s2 allele was found exclusively in the group of individuals without any pathology, consistent with observations that vacA s2 strains are minimally or non-ulcerogenic. ${ }^{80-84}$ On the other hand, recent studies of a worldwide collection of strains indicate that subtype s1c was observed exclusively in isolates from East Asia and appears to be the major s1 allele in that part of the world. Nevertheless, whether s1c strains are phenotypically different from sla and s1b strains remains to be determined..$^{68}$

In addition to these typical differences between vacA alleles, there is also considerable variation among different $H$. pylori strains with regard to the production of vacuolating cytotoxin. Thus, the vacuolating cytotoxin phenotype of an $H$. pylori strain is not only dependent on the amino acid sequence of VacA but may also be modulated by other strain-specific factors, such as the level of vacA transcription or the efficiency with which VacA is secreted. ${ }^{90}$ The considerable variation in these determinants may be relevant to the occurrence of different clinical outcomes in $H$. pyloriinfected humans. ${ }^{91}$

The high molecular weight immunodominant CagA protein encoded by the cytotoxin associated gene $A(\operatorname{cag} A)$, has long been one of the most intensely investigated putative virulence factors. However, its function has not been well understood. Recently, Odenbreit S. and colleagues reported that CagA is tyrosine-phosphorylated and induces changes in the tyrosine phosphorylation state of distinct proteins in gastric epithelial cells. ${ }^{92}$ The $\operatorname{cag} A$ gene is present in about $50-70 \%$ of $H$. pylori strains ${ }^{93}$ and virtually all of them produce a detectable local and systemic CagAantibody response in the human host. Several studies have reported that the $\operatorname{cag} A$ status is highly associated with the pathogenicity of $H$. pylori strains.

These features make it easy to correlate the $\operatorname{cag} A$ phenotype of the infective strains with a particular gastroduodenal disease by a regular blood test. ${ }^{94}$ The clinical isolates of $H$. pylori have been grouped into two broad families defined as type I and type II on the basis of whether they have the entire pathogenicity island (cag PAI), express the CagA protein, and secrete an active vacuolating cytotoxin VacA. ${ }^{93,95,96}$ Type I strains are positive for all these characteristics. In contrast, type II strains do not express CagA even though they have the gene, possess the vacA gene that is silent or encoded for non-toxic but immunoreactive protein, and/or have defective secretion mechanisms. ${ }^{77,97,98}$ In addition, only type I strains were able to elicit secretion of Interleukin 8 (IL-8), which is the mediator of neutrophil migration by epithelial cells in vitro. ${ }^{99,100}$ A number of epidemiological studies have shown that there is a strong correlation between infection with type I strains and occurrence of severe gastroduodenal diseases, whereas type II strains with attenuated virulence do not induce dramatic change in the gastric mucosa. ${ }^{97,101}$

Thus, H. pylori strains that express CagA cause more extensive inflammation of the gastric muco$\mathrm{sa},{ }^{99,100,102}$ and infections with these strains have been reported to be more likely to result in peptic ulceration, ${ }^{97,98}$ atrophic gastritis ${ }^{101}$ and gastric adenocarcinoma. ${ }^{102,103}$ These epidemiological studies are supported by experiments in animal models, where only the type 
I strains promote gastric damage similar to that observed in humans. ${ }^{11,104}$

To date, studies have shown that CagA is one of the proteins produced by the pathogenicity island (cag PAI). Recent studies using isogenic mutants strains lacking the cagA gene have shown that IL-8 induction may not be directly due to CagA protein but to the products of cag PAI genes. ${ }^{95,105,106,107}$ cag PAI is a 40 kilobase segment of DNA containing over 31 genes inserted into the chromosomal glutamate racemase gene. The presence in cag PAI of the short repeated sequences similar to that found in the insertion sequence 605 (IS605), and its different proportion of $\mathrm{G}+\mathrm{C}$ in comparison with the chromosomal DNA, suggests that this has been acquired by horizontal transfer.

Although cag PAI was acquired by a relatively recent event in evolutionary time, the structure of the cag PAI is not identical in all strains, which indicates that this region has gone through a series of rearrangements at different points during evolution. Cesini and colleagues suggested that after the initial event of integration of the island, cag PAI is found as a single uninterrupted unit in the same relative position on the chromosome. ${ }^{58,95,108}$ Subsequently, the interposition by one copy of the IS605 into its intermediate region has resulted in rearrangements and deletions within cag PAI that have led to the rise of $H$. pylori strains with varying virulence. ${ }^{95}$

Analysis of nucleotidic sequence has revealed that six of the cag PAI genes belong to a growing family of transporters whose subunits share extensive sequence, genetic organization, and functional similarities. At present, this secretion family is referred to as a type IV secretion system and is present in other bacteria species such as Agrobacterium tumefaciens, ${ }^{109}$ Bordetella pertussis, ${ }^{110}$ E. coli. ${ }^{111}$ and Brucella suis. ${ }^{112}$ The type IV secretion system is devoted to the transfer of a variety of multimolecular complexes across the bacterial membrane to the extracellular space or into other cells. The similarity of the H. pylori cag PAI genes with components of bacterial secretory pathways suggested that the expression of $H$. pylori virulence is triggered by contact with the host cell. Recently Odenbreit S. and colleagues provided evidences that the cag PAI system is involved in CagA secretion. ${ }^{82}$ In this way, the bacterial protein $\mathrm{CagA}$ is the virulence determinant that is actively translocated across the membrane of the gastric epithelial cells. ${ }^{95,107}$

The gastric epithelium represents the first line of active defense against $H$. pylori infection. However, this tissue not only serves as barrier to exclude pathogens but also secrets a number of inflammatory mediators that initiate the host immune response to pathogen invasion. In vivo and in vitro studies have shown that the bacterial infection induces chemokines secretion in gastric epithelial cells, such as IL-8 and GRO- $\alpha$, MIP-1 $\alpha$, ENA-78, and MCP-1, which have neutrophil attractant properties. It also induces inflammatory cytokines IL-1, IL- 6 and TNF- $\alpha$, which up-regulate the expression of IL-8 in epithelial cells. ${ }^{67,105,113}$ This epithelial proinflammatory cytokine/chemokine response is particularly important because it serves to amplify and spread the primary pathogenic signal that leads to a rapid mobilization of phagocytic cells to the sites of invasion. Proinflammatory cytokine response may be protective, but when chronically activated, it also disrupts the function and the integrity of the gastric epithelium. The infiltration of T-cells and basophils is activated by IL-8. However, neutrophils appear to be its major target. ${ }^{99}$ Activated neutrophils may be helpful, but they may also contribute to surface epithelial layer damage by leakage of potent intracellular enzymes and reactive products. Cytokines produced by infiltrated mononuclear phagocytes within the mucosa produce additional stimulation that induces gastric degeneration. ${ }^{113}$ Thereby, IL-8 appears to play a key role in the initiation of the local inflammatory and immune response that may contribute to the more serious sequels associated with $H$. pylori infection.

The importance of certain predicted coding regions of the cag PAI in the elicitation of chemokine response has been evaluated by mutations that suppressed or reduced the induction of IL-8 secretion by epithelial cells. These studies have shown that isogenic $\operatorname{cag} A$ mutants do not affect the expression of VacA and elicit IL-8 secretion to the same degree as does the wild-type parent strain. ${ }^{99,114,115}$ However, mutant strains with disruption of many other genes in the cag PAI suppress their ability to stimulate IL- 8 production. $95,106,107,116,117$

Censini and colleagues demonstrated that mutants in $c a g E, c a g G, c a g H, c a g I, c a g L$, and $c a g M$ genes lost their ability to induce IL-8 and blocked the tyrosine phosphorylation of CagA protein, while cag $N$ mutants were not affected. ${ }^{95,116}$ Knockout of $c a g E$ gene affected the activation of the immediate early response transcription factor nuclear factor $\mathrm{\kappa B}$ (NF- $\mathrm{\kappa B})$ in a gastric epithelial cell line. ${ }^{118}$ This protein, which is activated upon stimulation by a large variety of pathogenic agents, is present in virtually all cell types and plays an integral role in regulating the human immune response. ${ }^{119}$ The active form of NF- $\mathrm{KB}$ is located in the nucleus of the cell, where it activates transcription of target genes, including those encoding IL-1, IL-6, IL-8, and TNF- $\alpha .{ }^{118}$

Glocker E. and colleagues investigated the role of other cag PAI genes in NF- $\mathrm{kB}$ activation. ${ }^{120}$ They re- 
ported that while two genes (cagF and $c a g N)$ are not required for transcription factor activation, six genes (cagE, cagG, cagH, cagI, cagL, and cagM) are necessary, since isogenic $H$. pylori strains carrying mutations in these genes no longer induce NF-kB activity. Additionally, Keates S. and colleagues determined that gene products of the cag pathogenicity island are required for maximal activation of mitogen-activated protein kinases (MAPK) in gastric epithelial cells. MAPK regulate cell proliferation, differentiation, inflammatory responses, stress, and programmed death, which may help induce gastroduodenal inflammation, ulceration, and neoplasia. ${ }^{121}$ The integrity of whole cag PAI is also a prerequisite for efficient activation of early transcription factor AP-1, which is known for its immunostimulatory function ${ }^{113}$. Hence, these data support the view that the epithelial cytokine/chemokine response depends on multiple genes in the cag PAI of H. pylori.

\section{Vaccination development for clinical use and future of the $\boldsymbol{H}$. pylori infection}

The discovery of H. pylori as the causal agent of various gastroduodenal diseases has dramatically changed the medical approach to this bacterial species. Research on this bacterium's mechanisms of virulence has advanced substantially in a period of less than 20 years. The availability of the sequence of the $H$. pylori genome and functional characterization of the genes involved in virulence have considerably increased our understanding of the molecular genetic basis for the pathogenesis of $H$. pylori ${ }^{96,122}$ Although the specific genes involved in virulence are still being determined, the completed genome sequence should make it easier to determine the participation of these genes in the wide spectrum of pathological and clinical outcomes that follow H. pylori infection. The participation of several of these genes has already been confirmed by genetic disruption. It is now well established that urease and VacA protein are virulence factors of this organism. The cag PAI genes have also emerged as other wellconfirmed virulence participants.

Effective antibiotic-based therapies for eradicating H. pylori have been developed in recent years. At this time, the most proven effective treatment is a 2week course of treatment called triple therapy, which involves the use of two antibiotics and either an acid suppressor or a stomach lining shield. Two-week triple therapy kills the bacteria, reduces ulcer symptoms, and prevents its recurrence in more than $90 \%$ of patients. ${ }^{123}$ There is, however, an increasing problem of H. pylori antibiotic resistance. Antibiotics cannot be used to eradicate the infection from the whole popula- tion, especially in developing countries where their indiscriminate use has led to the emergence of $H$. pylori resistant strains. ${ }^{124}$ It is therefore predictable that although antibiotics are useful, the long-term consequence of large-scale eradication programs will be a reduction in the efficacy of antibiotic therapy. Vaccination, which has long been the most efficient medical intervention in controlling epidemiological infections, seems to represent the best alternative. Therefore, the development of a vaccine against $H$. pylori that confers long-term protective immunity is the best strategy to eradicate chronic $H$. pylori infection on a global scale and to avoid the problem of antibiotic resistance. ${ }^{125}$ This possibility has been the stimulus for intense research activity. Further investigation of $H$. pylori virulence factors has provided information that is being used in the development of novel therapies and vaccines to treat and prevent $H$. pylori infection.

Although the feasibility of inducing protective immune response to Helicobacter by vaccination was initially demonstrated in experimental Helicobacter felis/murine model, ${ }^{126}$ the development of a vaccine has been particularly successful in the more recent $H$. pylori/mouse models that mimics human infection. ${ }^{104,127}$ These models have permitted the testing of prophylactic and therapeutic vaccines containing different antigens, including whole inactivated cells, ${ }^{1}$ bacterial lysates, ${ }^{128}$ and several purified antigens. To date, researchers have identified several $H$. pylori antigens which confer protection against $H$. pylori infection or in eradicating an already established infection in the murine models, including purified VacA, ${ }^{104}$ urease (and its subunits) ${ }_{1}^{129} \mathrm{Cag} A,{ }^{130}$ heat shock proteins (HspA and HspB), ${ }^{1}$ and catalase. ${ }^{131}$ Therapeutic vaccination has also been successful in ferrets and Rhesus monkeys infected with Helicobacter mustelae and H. pylori, respectively. ${ }^{132,133}$

Most of these antigens have been given orally in combination with mucosal adjuvants, which improve their low immunoreactivity. ${ }^{127}$ However, the inherent toxicity of mucosal adjuvants has been the major limitation for their use as vaccines in humans. An alternative approach to circumvent this problem is the use of genetically detoxified heat labile enterotoxins of E. coli LTK63 or non-toxic mutant cholera toxin CT S61F. ${ }^{125,134,135}$ The challenge currently faced by several laboratories is to discover whether or not the promising results obtained in the animal model can be reproduced in humans.

A major question is how vaccination could be successful if $H$. pylori can survive for the lifetime of its human host, despite the vigorous immune response that is mounted against it. Nonetheless, studies in 
progress not only allow investigators to confirm the feasibility of the vaccination to prevent and/or cure gastroduodenal diseases, but also to understand how the host immune response prevents and/or exacerbates this $H$. pylori infection. A large body of evidence has indicated that the major subset of lymphocytes involved in immunity against invading $H$. pylori is the CD4+ T-lymphocytes which are divided into Type $1 \mathrm{~T}$ helper (Th1) and Type $2 \mathrm{~T}$ helper (Th2) phenotypes. ${ }^{136}$ Th1 cells produce a set of cytokines which activate macrophages and are responsible for cell-mediated protective responses. In contrast, Th2 cells produce cytokines, which are responsible for eosinophil activation, inhibition of several macrophage functions that provide phagocyte-independent protective responses, and strong antibody production, particularly $\operatorname{Ig} A$ and $\operatorname{Ig} G$, which are especially active on mucosal surfaces. ${ }^{137,138}$

In the stomach, IL-12 and IL-10 production has been implicated in the selection of Th1 and Th2 cells, respectively. The relative predominance of IL-12 in the human stomach, regardless of whether it is infected or not, favors the development of a subset of helper T cells that tend to produce interferon gamma, which is associated with Th1 cells and enhanced cell-mediated immunity ${ }^{127}$ More recently, several laboratories have shown that biopsies from gastric mucosa of normal, infected, and uninfected patients, revealed no or very low levels of mRNA of the classic Th2 cytokine IL-4. ${ }^{137,138}$ These studies support the notion that most infected humans have a Th1 response, which does not eradicate $H$. pylori infection. It is therefore predictable that a Th2 response would be more effective.

In contrast to natural infection, urease alone is able to induce relatively more IL-10 in animal models. ${ }^{139}$ These findings support the notion that vaccines, including whole-cell vaccines and native or recombinant urease or urease subunits, may be effective due to their ability to alter the selection of T-cell subsets. ${ }^{137}$ Additionally, the use of non-toxic LTK63 or CT S61F for oral vaccination induces a relatively greater Th2 cell response that can cure and prevent infection in H. felis/ mice models. ${ }^{128,129,135,139}$ Thus, with the discovery of the appropriate formulation and routes of administration, it is possible that vaccination could trigger an immune response that differs substantially from that induced by natural infection with $H$. pylori. Undoubtedly, the continuous efforts of laboratories around the world to develop a vaccine and therapeutic approaches may soon bring an end to the long evolutionary relationship between humankind and Helicobacter pylori.

\section{Acknowledgments}

We express our deep appreciation to Ann L. Lutterman-Aguilar for her generous help and criticism during the preparation of this paper.

\section{References}

1. Covacci A, Telford JL, Del Guidice G, Parsonnet J, Rappuoli R. Helicobacter pylori virulence and genetic geography. Science 1999;284(5418): 1328-1333.

2.W arren JR, Marshall B. Unidentified curved bacilli on gastric epithelium in active chronic gastritis. Lancet 1983;1:1273-1275.

3. Marshall BJ, Royce H, Annear DI, Goodwin CS, Pearman JW, W arren JR et al. 0 riginal isolation of Campylobacter pyloridis from human gastric mucosa. Microbios Lett 1984;25:83-88.

4. Ernst PB, Crowe SE, Reyes VE. How does Helicobacter pylori cause mucosal damage? The inflammatory response. Gastroenterology 1997; 113 Suppl 1:S35-S42.

5. Axon ATR. Are all Helicobacters equal? Mechanisms of gastroduodenal pathology and their clinical implications. Gut 1999;45 Suppl 1:11-14.

6. Hirai $Y, H$ ayashi $S$, Shimomura $H, O$ guma $K$, Yokota K. Association of Helicobacter pylori with gastroduodenal diseases. Jpn J Infect D is 1999; 52(5):183-197.

7. Marshall B,Armstrong J, McG echie D, G lancy R.Attempt to fulfill Koch's postulates for pyloric Campylobacter. Med J Aust 1985;142:436-439.

8. Morris A, N icholson $\mathrm{G}$. Ingestion of Campylobacter pylori causes gastritis and raised fasting pH.Am J Gastroenterol 1987;82:192-199.

9. Morris AJ, Ali MR, N icholson GI, Perez-Perez GI, Blaser MJ. Long-term follow-up of voluntary ingestion of Helicobacter pylori. Ann Intern Med 1991;114:662-663.

10. Howden CW. C linical expressions of H elicobacter pylori infection. Am J Med 1996;100 (Suppl):27S-34S.

11. Peura DA. Helicobacter pylori and ulcerogenesis. A m J Med. 1996; 100 suppl 5A:19S-26S.

12. Parsonnet J, Friedman GD, Vandersteen DP, Chang Y, Vogelman JH, $O$ rentreich $\mathrm{N}$ et al. Helicobacter pylori infection and the risk of gastric adenocarcinoma. N Engl J Med 1991;325:1127-1131.

13. N omura A, Stemmermann GN , Chyou PH, Kato I, Pérez-Pérez GI, Blaser MJ. Helicobacter pylori infection and gastric carcinoma among Japanese Americans in Hawaii. N Engl J Med1991; 325:1132-1136.

14. Alexander GA, Brawley OW. Association of Helicobacter pylori infection with gastric cancer. Mil Med 2000;165(1):21-27.

15. Huang JQ, H unt RH. Helicobacter pylori and gastric cancer -The clinicians' point of view. Aliment Pharmacol Ther 2000;14 Suppl 3:48-54.

16. Parsonnet J, Hansen S, Rodríguez L, G elb AB,W arnke RA, Jellum E et al. Helicobacter pylori and gastric lymphoma. N Engl J Med 1994;330:12671271.

17.Talley N J, Hunt RH.W hat role does Helicobacter pylori play in dyspepsia and nonulcer dyspepsia? Arguments for and against $\mathrm{H}$. pylori being associated with dyspeptic symptoms. Gastroenterology 1997;113 Suppl 1:S67-S77.

18. Parsonnet J. Helicobacter pylori:The size of the problem. Gut 1998;43 Suppl 1:S6-59.

19. Logan RP. Helicobacter pylori and gastric cancer. Lancet 1994;344(8929): 1078-1079.

20. W yatt JI, Rathbone BJ, Dixon MF, Heatley RV. Campylobacter pyloridis and acid-induced gastric metaplasia in the pathogenesis of duodenitis. J Clin Pathol 1987;40:841-848. 
21. Borhan-Manesh F, Farnum JB. Study of H elicobacter pylori colonization of patches of heterotopic gastric mucosa (HGM) at the upper esophagus. Dig Dis Sci 1993;38:142-146.

22. Paul G, Yardley JH. Gastric and esophageal Campylobacter pylori in patients with Barrett's esophagus. Gastroenterology 1988;95:216-218.

23. Morris A, N icholson G, Zwi J,Vanderwee M. Campylobacter pylori infection in Meckel's diverticula containing gastric mucosa. Gut 1989;30: 1233-1235.

24. Dye KR, Marshall BJ, Frierson HF Jr., Pambianco DJ, McC allum RW. Campylobacter pylori colonizing heterotopic gastric tissue in the rectum. Am J Clin Pathol 1990;93:144-147.

25. G asbarrini A, Franceschi F, G asbarrini G, Pola P. Extraintestinal pathology associated with Helicobacter infection. Eur I Gastroenterol Hepatol 1997;9:231-233.

26. Leontiadis GI, Sharman VK, Howden CW. N on-gastrointestinal tract associations of Helicobacter pylori infection. Arch Intern Med 1999;159: 925-940.

27. Pakodi F, A bdel-Salam O M, D ebreceni A, Mozsik G. Helicobacter pylori. $O$ ne bacterium and a broad spectrum of human disease! An overview. J Physiol Paris 2000;94(2):139-152.

28. Replogle ML, G laser SL, Hiatt RA, Parsonnet J. Biological sex as a risk factor for Helicobacter pylori infection in healthy young adults. Am J Epidemiol 1995;142(8):856-863.

29. Lam SK. Epidemiology and genetics of peptic ulcer. Gastroenterol Jpn 1993;28 Suppl 5:145-157.

30. Gerhard M, Lehn N, N eumayer N, Boren T, Rad R, Schepp W et al. Clinical relevance of the Helicobacter pylori gene for blood-group antigen-binding adhesin. Proc N atl A cad Sci U SA 1999;96(22):12778-12783.

31. Lee A, D ixon MF, D anon SJ, Kuipers E, Megraud F, Larsson H et al. Local acid production and Helicobacter pylori: $A$ unifying hypothesis of gastroduodenal disease. Eur J Gastroenterol Hepatol 1995;7:461-465.

32. Eurogast Study Group. Epidemiology of, and risk factors for, Helicobacter pylori infection among 3194 asymptomatic subjects in 17 populations. Gut 1993;34:1672-1676.

33. Forman D, Goodman KJ.The epidemiology of stomach cancer: Correlating the past with the present. Socioeconomic influences in early life can influence mortality in adult life. BMJ 2000;320(7251):1682-1683.

34. Martin DF, Montgomery E, D obek AS, Patrissi GA, Peura DA. Campylobacter pylori, N SAID s and smoking: Risk factors for peptic ulcer disease. Am J Gastroenterol 1989;84:1268-1272.

35. Correa P. Is gastric carcinoma an infectious disease? N Engl J Med 1991;325:1170-1171.

36. Toyonaga A, $O$ kamatsu H, Sasaki K, Kimura H, Saito T, Shimizu $S$ et al. Epidemiological study on food intake and Helicobacter pylori infection. Kurume Med J 2000;47(1):25-30.

37. Brenner H, Berg G, Lappus N , Kliebsch U, Bode G, Boeing H. Alcohol consumption and Helicobacter pylori infection: Results from the German $\mathrm{N}$ ational $\mathrm{H}$ ealth and $\mathrm{N}$ utrition Survey. Epidemiology 1999;10(3):214-218. 38. Buiatti E, Palli D, Decarli A, A madori D, Avellini C, Bianchi $S$ et al. A case-control study of gastric cancer and diet in Italy: II. Association with nutrients. Int J Cancer 1990;45:896-901.

39. Woodward M, Morrison C, McC oll K. An investigation into factors associated with Helicobacter pylori infection. J Clin Epidemiol 2000; 53(2):175-181.

40. Bardhan PK. Epidemiological features of Helicobacter pylori infection in developing countries. C lin Infect D is 1997;25(5):973-978.

41. Banatvala N, Mayo K, Megraud F, Jennings R, D eeks JJ, Feldman RA. The cohort effect and Helicobacter pylori. I Infect D is 1993;168:219-221.

42. Hopkins RJ, Russell RG, 0 'D onnoghue JM,W assevman SS, Lefkowitz A, Morris JG JR. Seroprevalence of Helicobacter pylori in Seventh-D ay Adventists and other groups in Maryland. Lack of association with diet.Arch Intern Med 1990;150:2347-2348.

43. Smoak BL, Kelley PW, Taylor D N . Seroprevalence of Helicobacter pyIori infection in a cohort of USA Army recruits. Am J Epidemiol 1994;139: 513-519.

salud pública de méxico / vol.43, no.3, mayo-junio de 2001
44. Teh BH, Lin JT, Pan W H, Lin SH, W ang LY, Lee TK et al. Seroprevalence and associated risk factors of Helicobacter pylori infection in Taiwan. Anticancer Res 1994:14:1389-1392.

45. Blecker U, Hauser B, Lanciers S, Peeters S, Suys B, Vandenplas Y. The prevalence of Helicobacter pylori-positive serology in asymptomatic children.J Pediatr Gastroenterol N utr 1993;16(3):252-256.

46. Malaty HM, Engstrand L, Pedersen N L, Graham DY.A study of twins. Helicobacter pylori infection: Genetic and environmental influences.A study of twins Ann Intern Med 1994;120:(12)982-986.

47. Bohmer CJ, Klinkenberg-Knol EC, Kuipers E], N iezen-de Boer MC, Schreuder $\mathrm{H}$, Schuckink-Kool $\mathrm{F}$ et al.The prevalence of Helicobacter pylori infection among inhabitants and healthy employees of institutes for the intellectually disabled. Am J Gastroenterol 1997;92(6):1000-1004.

48. Goodman KJ, Correa P, Tengana A ux HJ, Ramírez H, De Lan JP, Guerrero-Pepinosa 0 et al. Helicobacter pylori infection in the Colombian Andes:A population-based study of transmission pathways. Am J Epidemiol 1996;144:290-299.

49. D ominici P, Bellentani S, Di Biase AR, Saccoccio G, Le Rose A, Masutti $F$ et al. Familial clustering of $H$ elicobacter pylori infection: Population-based study. Br Med J 1999;319(7209):537-540.

50.Vaira D, Holton J, Menegatti M, Gatta L, Ricci C, Ali A et al. Routes of transmission of Helicobacter pylori infection. Ital I Gastroenterol Hepatol 1998 Suppl 3:S279-S285.

51. Langenberg W, Rauws EA, 0 udbier JH, Tytgat GN . Patient-to-patient transmission of Campylobacter pylori infection by fiberoptic gastroduodenoscopy and biopsy. J Infect D is 1990;161(3):507-511.

52. Fox JG . N on-human reservoirs of Helicobacter pylori. A liment PharmacolTher 1995;9 Suppl 2:93-103.

53. Figura N ,Vindigni C, Presenti L, Carducci A. N ew acquisitions in Helicobacter pylori characteristics. Ital J Gastroenterol Hepatol 1998;30 Suppl 3:S254-S258.

54. Eaton KA, Brooks CL, Morgan DR, Krakowka S. Essential role of urease in pathogenesis of gastritis induced by $\mathrm{H}$ elicobacter pylori in gnotobiotic piglets. Infect Immun 1991;59(7):2470-2475.

55. Seong-Kim J, Hoon-C hang J, II-C hung S, Sun-Yum J. Molecular cloning and characterization of the Helicobacter pylori fliD gene, an essential factor in flagellar structure and motility. J Bacteriol 1999;181(22):6969-6976.

56. W adstrom T, Hirmo S, Boren T. Biochemical aspects of Helicobacter pylori colonization of the human gastric mucosa. A liment Pharmacol Ther 1996;10 (Suppl 1):17-27.

57. Taylor N S, Hasubski AT, Fox JG, Lee A. Haemagglutination profiles of Helicobacter species that cause gastritis in man and animals.J Med Microbiol 1992;37(5):299-303.

58.Tomb JF, W hite 0 , Kerlavage AR, C layton RA, Sutton G G, Fleischmann $\mathrm{RD}$ et al. The complete genome sequence of the gastric pathogen Helicobacter pylori. Nature 1997;388(6642):539-547.

59. Marais A, Mendz GL, Hazell SL, Megraud F. Metabolism and genetics of Helicobacter pylori:The Genome Era. Microbiol Mol Biol Rev 1999;63(3): 642-674.

60. McGee DJ, Mobley HL. Mechanisms of Helicobacter pylori infection: Bacterial factors. Curr Top Microbiol Immunol 1999;241:155-180.

61. Moran AP. Helicobacter pylori lipopolysaccharide-mediated gastric and extragastric pathology.J Physiol Pharmacol 1999;50(5):787-805.

62. MuotialaA, H elander IM, Pyhala L, Kosunen TU, Moran AP. Low biological activity of Helicobacter pylori lipopolysaccharide. Infect Immun 1992;60:1714-1716.

63. Birkholz S, Knipp U, N ietzki C,A damek RJ, O pferkuch W. Immunological activity of lipopolysaccharide of Helicobacter pylori on human peripheral mononuclear cells in comparison to lipopolysaccharides of other intestinal bacteria. FEMS Immunol Med Microbiol 1993;6:317-324.

64. Bliss C M Jr, G olenbock DT, Keates S, Linevsky JK, Kelly C P. Helicobacter pylori lipopolysaccharide binds to CD 14 and stimulates release of interleukin-8, epithelial neutrophil-activating peptide 78 , and monocyte chemotactic protein 1 by human monocytes. Infect Immun 1998;66(11): 5357-5363. 
65.A ppelmelk BJ, N egrini R, Moran AP, Kuipers EJ. Molecular mimicry between Helicobacter pylori and the host.Trends Microbiol 1997;5(2): 70-73. 66. Claeys D, Faller $G$, Appelmelk BJ, N egrini R, Kirchner T.The gastric $\mathrm{H}+, \mathrm{K}+$-ATPase is a major autoantigen in chronic Helicobacter pylori gastritis with body mucosa atrophy. Gastroenterology 1998;115(2): 340347.

67. ShimoyamaT, Crabtree JE. Bacterial factors and immune pathogenesis in Helicobacter pylori infection. Gut 1998;43 (Suppl) 1:S2-S5.

68. Leunk RD, Johnson PT, D avid BC, Kraft W G, Morgan DR. Cytotoxic activity in broth-culture filtrates of Campylobacter pylori. J Med Microbiol 1988:26:93-99

69. Figura N , Guglielmetti P, Rossolini A, Barberi A, C usi G, Musmanno RA et al. Cytotoxin production by Campylobacter pylori strains isolated from patients with peptic ulcers and from patients with chronic gastritis only. J Clin Microbiol 1989;27:225-226.

70. Cover TL, Blaser MI. Purification and characterization of the vacuolating toxin from Helicobacter pylori.J Biol Chem 1992;267:10570-10575.

71.Telford JL, G hiara P, D ell'O rco M, C omanducci M, Burroni D, Bugnoli M et al. Gene structure of the Helicobacter pylori cytotoxin and evidence of its key role in gastric disease.J Exp Med 1994;179(5):1653-1658.

72. Molinari M, G alli C, N orais N, Telford JL, Rappuoli R, Luzio JP et al. Montecucco $C$. Vacuoles induced by Helicobacter pylori toxin contain both late endosomal and lysosomal markers.J Biol C hem 1997;272(40): 25339-25344.

73. Reyrat JM, Pelicic V, Papini E, Montecucco C, Rappuoli R, Telford JL. Towards deciphering the Helicobacter pylori cytotoxin. Mol Microbiol 1999;34(2):197-204.

74. Satin B, N orais N, Telford J, Rappuoli R, Murgia M, Montecucco C et al. Effect of $\mathrm{H}$ elicobacter pylori vacuolating toxin on maturation and extracellular release of procathepsin $D$ and on epidermal growth factor degradation. J Biol Chem 1997;272(40):25022-25028.

75. Pagliaccia C, de Bernard M, Lupetti P, Ji X, Burroni D, Cover TL et al. The $\mathrm{m} 2$ form of the Helicobacter pylori cytotoxin has cell type-specific vacuolating activity. Proc N atl A cad Sci U SA 1998:95(17):10212-10217. 76. Yahiro K, N iidome T, Kimura M, HatakeyamaT,A oyagi H, Kurazono H et al. Activation of Helicobacter pylori VacA toxin by alkaline or acid conditions increases its binding to a $250-\mathrm{kD}$ a receptor protein-tyrosine phosphatase beta. J Biol Chem 1999;274(51):36693-36699.

77. Atherton JC, Cao P, Peek RM Jr, Tummuru MK, Blaser MJ, Cover TL. Mosaicism in vacuolating cytotoxin alleles of Helicobacter pylori. Association of specific vacA types with cytotoxin production and peptic ulceration. J Biol Chem 1995;270(30):17771-17777.

78. Van Doorn LJ, Figueiredo C, Sanna R, Pena S, Midolo P, N g EK et al. Expanding allelic diversity of Helicobacter pylori vacA. J Clin Microbiol 1998;36(9):2597-2603

79. Morales-Espinosa R, Castillo-Rojas G, Gonzalez-Valencia G, Ponce de Leon $S, C$ ravioto $A$, Atherton JC et al. C olonization of Mexican patients by multiple Helicobacter pylori strains with different vacA and cagA genotypes. I Clin Microbiol 1999;37(9):3001-3004.

80. Atherton JC, Peek RM, Tham KT, Cover TL, Blaser MJ. Clinical and pathological importance of heterogeneity in vacA, the vacuolating cytotoxin gene of Helicobacter pylori. Gastroenterology 1997; 112: 92-99.

81. Han SR, Schreiber HJ, Bhakdi S, Loos M, Maeurer MJ. VacA genotypes and genetic diversity in clinical isolates of Helicobacter pylori. Clin Diagn Lab Immunol 1998;5(2):139-145.

82. Ito Y, Azuma T, Ito S, Miyaji H, Hirai M, Yamazaki Y et al. Analysis and typing of the vacA gene from cagA-positive strains of Helicobacter pylori isolated in Japan. J Clin Microbiol 1997;35(7):1710-1714.

83. Stephens JC, Folwell AM, Swann RA, Rathbone BJ. Helicobacter pylori cagA status, vacA genotypes and ulcer disease [abstract]. G ut 1996;39 Suppl 1:A2.

84. Kidd M, Lastovica AJ, Atherton J C, Louw JA. Heterogeneity in the Helicobacter pylori vacA and cagA genes:Association with gastroduodenal disease in South Africa? Gut 1999;45:499-502.
85. Basso D, N avaglia F, Brigato L, Piva M G, Toma A, G reco E et al. A nalysis of Helicobacter pylori vacA and cagA genotypes and serum antibody profile in benign and malignant gastroduodenal diseases. Gut 1998;43(2): 182-186.

86. Van Doorn LJ, Figueiredo C, Rossau R, Jannes G, Van Asbroek M, Sousa JC et al. Typing of Helicobacter pylori vacA gene and detection of cagA gene by PCR and reverse hybridization.J C lin Microbiol 1998;36(5): 1271-1276.

87. Strobel S, Bereswill S, Balig P,A Allgaier P, Sonntag HG , Kist M. Identification and analysis of a new vacA genotype variant of Helicobacter pylori in different patient groups in G ermany.J C lin Microbiol 1998;36(5): 1285-1289.

88. Maeda $\mathrm{S}, \mathrm{O}$ gura $\mathrm{K}$, Yoshida $\mathrm{H}$, Kanai F, Ikenoue T, Kato $\mathrm{N}$, et al. Major virulence factors, VacA and $\mathrm{CagA}$, are commonly positive in Helicobacter pylori isolates in Japan. Gut 1998;42:338-343.

89. Evans DG, Q ueiroz D M, Mendes EN, Evans DJ Jr. Helicobacter pylori cagA status and $s$ and $m$ alleles of vacA in isolates from individuals with a variety of H. pylori-associated gastric diseases. J Clin Microbiol 1998; 36(11):3435-3437

90. Perales G, Sanchez J, Mohar A, Lara-Lemus R, Hernandez A, Herrera$G$ oepfert $R$ et al. Single-step PCR amplification and enzyme restriction analysis of the entire Helicobacter pylori cytotoxin vacA gene for genetic variability studies. FEMS Microbiol Lett 1999;178(1):55-62.

91. Forsyth MH,A therton JC, Blaser MJ, Cover TL. H eterogeneity in levels of vacuolating cytotoxin gene (vacA) transcription among Helicobacter pylori strains. Infect Immun 1998:66(7):3088-3094.

92. 0 denbreit S, Puls J, Sedlmaier B, G erland E, Fischer W, Haas R.Translocation of Helicobacter pylori CagA into gastric epithelial cells by type IV secretion. Science 2000;287(5457):1497-500.

93. Xiang Z, Censini S, Bayeli PF, Telford JL, Figura N, Rappuoli R et al. A nalysis of expression of $\mathrm{C}$ agA and VacA virulence factors in 43 strains of Helicobacter pylori reveals that clinical isolates can be divided into two major types and that CagA is not necessary for expression of the vacuolating cytotoxin. Infect Immun 1995;63:94-98.

94. Atherton JC. H. pylori virulence factors. Br Med Bull 1998;54(1): 105-120.

95. C ensini S, Lange C, Xiang Z, C rabtree JE, G hiara P, Borodovsky M et al. cag, a pathogenicity island of $\mathrm{Helicobacter}$ pylori, encodes type I-specific and disease-associated virulence factors. Proc N atl Acad Sci U SA 1996; 93(25):14648-14653.

96. D oig P, de Jonge BL,AIm RA, Brown ED, U ria-N ickelsen M, N oonan B et al. Helicobacter pylori physiology predicted from genomic comparison of two strains. Microbiol Mol Biol Rev 1999;63(3):675-707.

97.W eel JF, van der Hulst RW, GerritsY, Roorda P, Feller M, D ankert J et al. The interrelationship between cytotoxin-associated gene $A$, vacuolating cytotoxin, and Helicobacter pylori related diseases. J Infect $D$ is 1996;173: 1171-1175.

98. Covacci A, Censini S, Bugnoli M, Petracca R, Burroni D, Macchia G et al. Molecular characterization of the $128-\mathrm{kD}$ a immunodominant antigen of Helicobacter pylori associated with cytotoxicity and duodenal ulcer. Proc $N$ atl Acad Sci USA 1993:90:5791-5795.

99. C rabtree JE, C ovacci A, Farmery SM, X iang Z, Tompkins DS, Perry S et al. Helicobacter pylori induced interleukin-8 expression in gastric epithelial cells is associated with CagA positive phenotype. J C lin Pathol 1995;48: 41-45.

100. Crabtree JE, Farmery SM, Lindley IJ, Figura N, Peichl P, Tompkins DS. C agA/ cytotoxic strains of Helicobacter pylori and interleukin-8 in gastric epithelial cell lines. J Clin Pathol 1994;47:945-950.

101. Kuipers EJ, Perez-Perez GI, Meuwissen SG, Blaser MJ. Helicobacter pylori and atrophic gastritis: Importance of the cagA status. J N atl Cancer Inst 1995:87:1777-1780.

102. Cover TL, G lupczynski Y, Lage AP, Burette A, Tummuru MK, PerezPerez $\mathrm{GI}$ et al. Serologic detection of infection with cagA+ Helicobacter pylori strains. J Clin Microbiol 1995;33(6):1496-1500. 
103. Blaser MJ, Perez-Perez GI, Kleanthous H, C over TL, Peek RM, Chyou $\mathrm{PH}$ et al. Infection with Helicobacter pylori strains possessing cagA is associated with an increased risk of developing adenocarcino ma of the stomach. Cancer Res 1995;55:2111-2115.

104. Marchetti M, Arico B, Burroni D, Figura N, Rappuoli R, G hiara P. D evelopment of a mouse model of Helicobacter pylori infection that mimics human disease. Science 1995;267(5204):1655-1658.

105. Maeda S, Yoshida H, Ikenoue T, 0 gura K, Kanai F, Kato N et al. Structure of cag pathogenicity island in Japanese Helicobacter pylori isolates. Gut 1999:44:336-341.

106.A ko pyants N S, C lifton SW, Kersulyte D, C rabtree JE,Youree BE, Reece $\mathrm{CA}$ et al.A nalyses of the cag pathogenicity island of $\mathrm{H}$ elicobacter pylori. Mol Microbiol 1998;28(1):37-53

107. Tummuru MK, Sharma SA, Blaser MJ. Helicobacter pylori picB, a homologue of the Bordetella pertussis toxin secretion protein, is required for induction of IL-8 in gastric epithelial cells. Mol Microbiol 1995;18: 867-876.

108.A Im RA, Ling LS, Moir DT, King BL, Brown ED, D oig PC et al. Genomic-sequence comparison of two unrelated isolates of the human gastric pathogen Helicobacter pylori. N ature 1999;397(6715):176-180.

109. Christie PJ. Agrobacterium tumefaciens T-C omplex Transport A pparatus:A paradigm for a new family of multifunctional transporters in eubacteria. J Bacteriol 1997;179 (10): 3085-3094.

110. C raig-Mylius KA,A W eiss A. Mutants in the ptIA-H genes of Bordetella pertussis are deficient for pertussis toxin secretion. FEMS Microbiol Lett 1999;179(2):479-484.

111. Harris RL, Sho II KA, C onrad MN , D resser ME, Silverman PM. Interaction between the F plasmid TraA (F-pilin) and TraQ proteins. Mol Microbiol 1999;34(4):780-791.

112. 0 'C allaghan $D, C$ azevieille $C$, Allardet-Servent A, Boschiroli ML, Bourg $G$, Foulongne $V$ et al. A homologue of the Agrobacterium tumefaciens VirB and Bordetella pertussis PtI type IV secretion systems is essential for intracellular survival of Brucella suis. Mol Microbiol 1999; 33(6):1210-1220.

113. N aumann M, W essler S, Bartsch C,W ieland B, C ovacci A, H aas $R$ et al. Activation of activator protein 1 and stress response kinases in epithelial cells colonized by Helicobacter pylori encoding the cag pathogenicity island. J Biol Chem 1999;274(44):31655-31662.

114. Tummuru MK, C over TL, Blaser MJ. Mutation of the cytotoxin-associated cagA gene does not affect the vacuo lating cytotoxin activity of Helicobacter pylori. Infect Immun 1994;62(6):2609-2613.

115. Sharma SA, Tummuru MK, Miller GG, Blaser MJ. Interleukin-8 response of gastric epithelial cell lines to Helicobacter pylori stimulation in vitro. Infect Immun 1995;63(5):1681-1687.

116. Segal ED, Lange C, C ovacci A, Tompkins LS, Falkow S. Induction of host signal transduction pathways by Helicobacter pylori. Proc $\mathrm{N}$ atl Acad Sci U SA 1997:94(14):7595-7599.

117. C rabtree JE. Inflammatory mediators in gastroenterology. 0 verview. Eur J Gastroenterol Hepatol 1997;9(11):1023-1025.

118. Munzenmaier A, Lange C, G locker E, Covacci A, Moran A, Bereswill S et al.A secreted/shed product of Helicobacter pylori activates transcription factor nuclear factor-kappa B. J Immunol 1997;159(12):6140-147.

119. Baeuerle PA, Baltimore D. I kappa B:A specific inhibitor of the N Fkappa B transcription factor. Science 1988;242:540-546.

120. G locker E, Lange C, Covacci A, Bereswill S, Kist M, Pahl HL. Proteins encoded by the cag pathogenicity island of $\mathrm{H}$ elicobacter pylori are required for N F-kappaB activation. Infect Immun 1998;66(5):2346-2348.

121. Keates S, Keates AC, W arny M, Peek RM Jr, Murray PG, Kelly CP. $D$ ifferential activation of mitogen-activated protein kinases in $A G S$ gastric epithelial cells by cagt and cag- Helicobacter pylori. J Immunol 1999;163(10):5552-5559.

122.G E Z,Taylor DE.C ontributions of genome sequencing to understanding the biology of Helicobacter pylori. Annu Rev Microbiol 1999;53:353-387.

123. Soll AH. Consensus conference. Medical treatment of peptic ulcer disease. Practice guidelines. Practice Parameters C ommittee of the A merican College of Gastroenterology. JAMA 1996;275(8):622-629.

124. Megraud F. Resistance of Helicobacter pylori to antibiotics. Aliment Pharmacol Ther 1997;11 Suppl 1:43-53.

125. Crabtree JE. Eradication of chronic Helicobacter pylori infection by therapeutic vaccination. Gut 1998;43(1):7-8.

126. Blanchard TG , C zinn SJ, N edrud JG. Host response and vaccine development to Helicobacter pylori infection. Curr Top Microbiol Immunol 1999;241:181-213.

127. G hiara P, Rossi M, Marchetti M, Di Tommaso A,Vindigni C, Ciampolini $\mathrm{F}$ et al. Therapeutic intragastric vaccination against Helicobacter pylori in mice eradicates an otherwise chronic infection and confers protection against reinfection. Infect Immun 1997;65(12):4996-5002.

128. D oidge C, G ust I, LeeA, Buck F, H azell S, Manne U.Therapeutic immunization against Helicobacter pylori infection. Lancet 1994 343:913-914.

129. Corthesy-Theulaz I, Porta N, G lauser M, Saraga E,Vaney A-C, H ass R et al. 1995. 0 ral immunization with Helicobacter pylori urease $B$ subunit as a treatment against Helicobacter infection in mice. Gastroenterology 109:115-121.

130. Marchetti M, Rossi M, G iannelli V, Giuliani M M, Pizza M, C ensini S et al. Protection against Helicobacter pylori infection in mice by intragastric vaccination with $\mathrm{H}$. pylori antigens is achieved using a non-toxic mutant of $\mathrm{E}$. coli heat-labile enterotoxin (LT) as adjuvant.Vaccine 1998;16(1):33-37.

131. Radcliff FJ, H azell SL, Kolesnikow T, D oidge C, Lee A. Catalase, a novel antigen for Helicobacter pylori vaccination. Infect Immun 1997; 65(11): 4668-4674.

132. C uenca R, Blanchard TG , C zinn SJ, N edrud JG , Monath TP, Lee CK et al. Therapeutic immunization against $\mathrm{Helicobacter}$ mustelae in naturally infected ferrets. Gastroenterology 1996;110(6):1770-1775.

133. D ubois A, Berg DE, Incecik ET, Fiala N , Heman-Ackah LM, D el Valle J et al. Host specificity of Helicobacter pylori strains and host responses in experimentally challenged nonhuman primates. Gastroenterology 1999;116(1):90-96.

134. Pizza M, Fontana MR, Giuliani M M, D omenighini M, Magagnoli C, GiannelliV et al.A genetically detoxified derivative of heat-labile Escherichia coli enterotoxin induces neutralizing antibodies against the A subunit. J Exp Med 1994;180(6):2147-2153.

135.Yamamoto S, Kiyono H,Yamamoto M, Imaoka K, Fujihashi K,Van Ginkel FW et al.A nontoxic mutant of cholera toxin elicitsTh2-type responses for enhanced mucosal immunity. Proc Natl Acad Sci USA 1997; 94(10):5267-5272.

136. Romagnani S.Th1/Th2 cells. Inflamm Bowel D is 1999;5(4): 285-294. 137. Haeberle HA, Kubin M, Bamford KB, Garofalo R, Graham DY, ElZaatari $F$ et al. Differential stimulation of interleukin-12 (IL-12) and IL-10 by live and killed Helicobacter pylori in vitro and association of IL-12 production with gamma interferon-producing $T$ cells in the human gastric mucosa. Infect Immun 1997;65(10):4229-4235.

138. ZeveringY, Jacob L, Meyer TF. N aturally acquired human immune responses against Helicobacter pylori and implications for vaccine development. Gut 1999;45(3):465-474.

139. Blanchard TG, N edrud JG , C zinn SJ. Local and systemic antibody responses in humans with $\mathrm{Helicobacter}$ pylori infection. C an J G astroenterol 1999;13(7):591-594 . 